\title{
PERTANGGUNGJAWABAN PELAKU USAHA ATAS KLAUSULA EKSONERASI YANG MERUGIKAN KONSUMEN PADA NOTA LAUNDRY ${ }^{*}$
}

\author{
Oleh: \\ Kadek Ayu Desi Candra Dewi** \\ A.A. Ketut Sukranatha ${ }^{* * *}$ \\ Program Kekhususan Hukum Bisnis \\ Fakultas Hukum Universitas Udayana
}

\begin{abstract}
ABSTRAK
Pesatnya perekonomian saat ini membuat para pelaku usaha mendirikan bidang usaha jasa laundry sehingga konsumen dimudahkan dalam segala hal. Namun konsumen dirugikan dengan tercantumnya klausula eksonerasi di dalam nota laundry oleh pelaku usaha. Hal tersebut bertentangan dengan UndangUndang Nomor 8 Tahun 1999 Tentang Perlindungan Konsumen. Apabila terjadi kelalaian, pelaku usaha harus mengganti kerugian yang ditimbulkan. Tetapi pada pelaksanaanya pelaku usaha tidak memberikan ganti kerugian sebagaimana mestinya. Permasalahan yang diangkat dalam penelitian ini adalah mengapa pelaku usaha mencantumkan klausula eksonerasi dan bagaimana pelaksanaan pertanggungjawaban yang dilakukan oleh pelaku usaha terhadap konsumen. Metode yang digunakan adalah metode yuridis empiris dengan pendekatan peraturan perundang-undangan, sifat yang dipakai pada penulisan ini adalah deskriptif dan wawancara dan juga bahan hukum sekunder yaitu studi dokumen dan literatur. Hasil dan pembahasannya yaitu pelaku usaha memiliki hak untuk mencantumkan klausula eksonerasi tetapi pada prinsipnya klausula eksonerasi tersebut dilarang untuk dicantumkan sesuai dengan ketentuan Pasal 18 ayat (1), pencantuman tersebut dilakukan karena pelaku usaha tidak mengetahui bahwa itu dilarang oleh undang-undang. Selain itu pelaku usaha harus memberikan pertanggungjawaban berupa bentuk ganti rugi. Untuk mencegah hal tersebut perlu adanya sosialisasi dari pihak pemerintah mengenai aturan dalam pencantuman klausula eksonerasi.
\end{abstract}

\footnotetext{
*Jurnal ini merupakan diluar ringkasan skripsi

**Kadek Ayu Desi Candra Dewi adalah mahasiswi aktif Fakultas Hukum Universitas Udayana

${ }^{* * *}$ A.A. Ketut Sukranatha, SH., MH adalah dosen Fakultas Hukum Universitas Udayana Korespodensi : agung_sukranatha@unud.ac.id
} 
Kata Kunci: Pertanggungjawaban, Klausula Eksonerasi, Nota Laundry.

\begin{abstract}
The rapid growth of economy nowdays has made business people establish laundry service businesses so that consumers are facilitated in everything. but, consumers are harmed by the existence of the exoneration clause in the laundry note by the business actor. This is contrary to Law Number 8 of 1999 concerning Consumer Protection. If there is any default, the business actor must replace the losses incurred. But in its implementation the business actor does not provide compensation as appropriate. The problem raised in this study is why business actors include the exoneration clause and how the implementation of accountability carried out by business actors to consumers. The method used is an empirical juridical method with a statutory approach, other than that, in this writing used descriptive and interview methods also secondary legal materials, namely the study of documents and literature. The results of the discussion are: the business actor has the right to include the exoneration clause but in principle, the exoneration clause is prohibited from being included in accordance with the provisions of section 18 of article (1), the inclusion is done because the business actor does not know that it is prohibited by law. In addition, business actors must provide accountability in the form of compensation. To prevent this, there need to be a socialization from the government regarding the rules for the inclusion of the exoneration clause.
\end{abstract}

Key Words: Accountability, Exoneration Clause, Laundry Note.

\title{
I. PENDAHULUAN
}

\subsection{Latar Belakang}

Perkembangan era perekonomian terjadi secara pesat dan cepat memudahkan masyarakat untuk menggunakan jasa. Beredarnya macam-macam jasa yang ada di Indonesia membuat para pelaku usaha memikirkan peluang bisnis yang akan memberikan keuntungan secara signifikan dan secara cepat. Hal 
ini didasarkan pada kebutuhan efisiensi serta efektifitas kerja. ${ }^{1}$ Salah satu jasa yang sangat diminati dan banyak digunakan oleh konsumen adalah jasa laundry. Terlebih lagi semakin hari banyaknya pertumbuhan penduduk dan besarnya tingkatan kebutuhan konsumen menggunakan jasa laundry ini membuat pelaku usaha untuk mendirikannya dan jasa dibidang laundry ini memberikan income yang secara terus menerus akan menguntungkan bagi pelaku usaha. Bisnis laundry ini merupakan bisnis dibidang jasa yang bilamana kepuasaan konsumen menjadi hal yang paling penting dan diutamakan. Akan tetapi tidak sedikit pula, banyak ditemukan konsumen yang resah akan kinerja atau pelayanan dari sebuah jasa laundry tersebut.

Ketidakpuasaan tersebut merupakan kesalahan dari pelaku usaha antara lain yaitu pakaian yang mengkerut, pakaian yang warnanya menjadi luntur, atau bahkan pakaian yang menjadi rusak, hilang dan pada nota laundry dicantumkan klausula baku yang dimana sering terdapat klausula eksonerasi. Perjanjian dengan syarat-syarat eksonerasi disebut pula perjanjian dengan syarat-syarat untuk pembatasan berupa penghapusan ataupun pengalihan tanggungjawab. ${ }^{2}$ Perjanjian yang terdapat nota-nota laundry dikenal dengan istilah klausula eksonerasi. Dalam pelaksanaannya dimasyarakat pencantuman klausula eksonerasi pada nota laundry merupakan salah satu bentuk penghindaran

${ }^{1}$ Az. Nasution, 1995, Karya Ilmiah Tentang Perlindungan Konsumen dan Peradilan di Indonesia, Badan Pembinaan Hukum Nasional, Departemen Kehakiman RI, h. 16.

2 A.A. Gde Agung Brahmanta, 2016, "Perlindungan Hukum Bagi Konsumen Dalam Perjanjian Baku Jual Beli Perumahan Dengan Pihak Pengembang Di Bali", Acta Comitas Jurnal Hukum Kenoktariatan, Vol. 1, No. 02 , URL

https://ojs.unud.ac.id/index.php/ActaComitas/article/view/24953/16186.

(Diakses tanggal 22 April 2019). 
tanggungjawab pelaku usaha atas complain terhadap kerusakan barang dari jasa yang digunakannya.

Adanya ketidaknyamanan dari konsumen membuat pelaku usaha harus mempertanggungjawabkan perbutannya. Pada prinsipnya, tanggungjawab pelaku usaha telah diatur di dalam Undang-Undang Perlindungan Konsumen Nomor 8 Tahun 1999 Tentang Perlindungan Konsumen (selanjutnya disebut UUPK) pada Pasal 19 ayat (2) yang menyatakan bahwa pengembalian uang sesuai dengan yang telah ditetapkan serta, penggantian barang dan/atau jasa setara dengan nilainya atau perawatan kesehatan dan/atau pemberian santunan yang sesuai dengan ketentuan peraturan perundang-undangan yang berlaku. Tidak sedikit dari pelaku usaha menjalankan usahanya menerapkan perjanjian baku, dalam perjanjian baku tersebut sering terdapat klausula eksonerasi yang sesungguhnya sangat merugikan pihak konsumen.

\subsection{Rumusan Masalah}

Berdasarkan latar belakang tersebut dapat ditarik rumusan masalah yaitu sebagai berikut:

1. Mengapa pelaku usaha laundry mencantumkan klausula eksonerasi?

2. Bagaimana bentuk pelaksanaan pertanggungjawaban pelaku usaha jasa laundry terhadap konsumen yang mencantumkan ketentuan klausula eksonerasi pada nota laundry di desa Seminyak kecamatan Kuta?

\subsection{Tujuan Penulisan}

Adapun tujuan dari penulis adalah untuk mengetahui dan memahami faktor penyebab pelaku usaha tidak melaksanakan 
ketentuan perundang-undangan dan pertanggungjawaban pelaku usaha dalam bentuk ganti kerugian kepada konsumen mengacu pada ketentuan UUPK No. 8 tahun 1999.

\section{ISI MAKALAH}

\subsection{Metode Penelitian}

Jenis penelitian ini menggunakan metode hukum yuridis empiris. Penelitian hukum empiris menurut Soerjono Soekanto adalah penelitian datanya yang didapatkan secara langsung dari masyarakat mengenai perilakunya. ${ }^{3}$ Teknik semacam ini digunakan untuk penelitian yang sifatnya studi dekriptif atau ekploratif. ${ }^{4}$

Penelitian hukum empiris merupakan penelitian yang beranjak dari adanya kesenjangan antara das sollen (norma keharusan) dan das sein (apa yang sebenarnya terjadi didalam kenyataan yang tidak sesuai dengan keharusan). Hal ini berarti adanya kesenjangan antara teori dengan pelaksanaanya atau teori dengan fakta hukum yang ada. Kesenjangan antara das sollen dengan das sein terjadi pada pelaku usaha laundry di Desa Seminyak Kecamatan Kuta yang tidak memberikan ganti kerugian sehingga tidak sesuai dengan peraturan UUPK dalam Pasal 19 dan didalam nota laundry ditemukan adanya klausula eksonerasi yang tidak sesuai dengan UUPK pada Pasal 18.

\subsection{Hasil dan Pembahasan}

3 Soerjono Soekanto, 2012, Pengantar Penelitian Hukum, UI-PRESS, Jakarta, h. 50.

4 Fakultas Hukum Universitas Udayana, 2013, Pedoman Pendidikan Fakultas Hukum Universitas Udayana, Denpasar, h. 86. 


\subsubsection{Pencantuman Klausula Eksonerasi oleh Pelaku Usaha Laundry}

Setiap manusia membutuhkan jasa ataupun barang untuk memenuhi kebutuhan hidupnya. Kebutuhan manusia terdidi dari berbagai macam bentuk dan begitu pula pelaku usaha juga membutuhkan konsumen dalam mengembangkan usahanya. Sehingga tanpa adanya konsumen, pelaku usaha tidak dapat menjalankan usahanya. Salah satu jasa yang sering digunakan bahkan dibutuhkan oleh konsumen adalah jasa laundry. Pada umumnya setiap terjadinya pemakaian jasa, biasanya pelaku usaha laundry akan menggunakan nota. Akan tetapi didalam nota laundry tersebut pelaku usaha mencantumkan klausula eksonerasi yang sebagaimana merupakan hak dari pelaku usaha tersebut. Biasanya hak-hak tersebut merupakan hak yang menguntungkan bagi pelaku usaha. Perjanjian baku atau perjanjian eksonerasi merupakan perjanjian yang dibuat secara sepihak oleh pelaku usaha dimana perjanjian tersebut harus disepakati oleh pihak konsumen. ${ }^{5}$ Pencantuman klausula eksonerasi yang dianggap hak oleh pelaku usaha merupakan halhal yang dilarang oleh undang-undang.tetapi pelaku usaha biasanya memiliki alasan-alasan tertentu mengapa pelaku usaha laundry mencantumkan klausula eksonerasi dalam nota untuk menunjang kegiatan usahanya.

Berdasarkan hasil wawancara dengan pemilik usaha laundry di wilayah Seminyak yang dilakukan pada tanggal 22 April 2019 didua tempat yaitu Quick Laundry dan Jayanata Laundry

\footnotetext{
${ }^{5}$ Anak Agung Adi Lestari, 2016, "Perjanjian Baku Dalam Jual Beli Kredit Sepeda Motor Ditinjau Dari Undang-Undang Nomor 8 Tahun 1999", Jurnal Magister Hukum udayana, Vol. 5, No. 2, URL: https://ojs.unud.ac.id/index.php/jmhu/article/view/22445/15663 (Diakses tanggal 22 April 2019).
} 
diketahui bahwa pemilik usaha Laundry mencantumkan klausula eksonerasi dalam kegiatan usahanya untuk meminimalisir kerugian yang akan dialami oleh pelaku usaha laundry. Ibu Ni Luh Eva Astuti Dewi selaku pemilik Jayanata Laundry menyatakan bahwa dia mencantumkan klausula eksonerasi karena merasa hal tersebut merupakan hak dari para pelaku usaha tersebut.

Selain itu menurut Bapak Ketut Dharma, selaku pemilik Quick Laundry mengatakan bahwa dia mencantumkan klausula eksonerasi karena memang sudah hak dari pelaku usaha untuk menerima pembayaran sesuai dengan kesepakatan dan jasa yang digunakan oleh konsumen sehingga tidak merugikan pelaku usaha. Jika pakaian yang di laundry tersebut tidak diambil selama 1 (satu) bulan bukan menjadi tanggung jawab dari pihak pelaku usaha laundry karena batas waktu pencucian di Quick Laundry tersebut hanyalah 1 bulan diluar dari 1 bulan dinggap konsumen mengerti perjanjian yang dibuat oleh pelaku usaha dan tidak memberatkan atau menuntut ganti kerugian kepada pihak pelaku usaha.

Tetapi menjadi persoalan dikarenakan kedua narasumber pemilik laundry tidak mnegetahui bahwa pencantuman klausul eksonerasi merupakan hal yang dilarang oleh peraturan perundang-undangan. Hal ini bertolak belakang dengan apa yang diatur di dalam UUPK pada Pasal 18 ayat (1) menyatakan bahwa pelaku usaha dalam menawarkan barang dan/atau jasa yang ditujukan untuk diperdagangkan dilarang membuat atau mencantumkan klausula baku pada setiap dokumen dan/atau perjanjian.

Tetapi pada dasarnya pelaku usaha laundry tersebut tetap mencantumkan klausula baku atau yang sering disebut dengan klausula eksonerasi ini sehingga apabila terjadi kelalaian atau 
kesalahan dari penyedia jasa maka menyebabkan kerugian pada pihak konsumen. Adanya pencantuman klausula eksonerasi dalam nota laundry dikarenakan pemilik kurang mengetahui aturan terkait hukum serta pengetahuan secara hukum tentang klausula eksonerasi yang membuat pelaku usaha tidak mengetahui bahwa klausula yang terdapat pada nota laundry tersebut dilarang oleh undang-undang. Sehingga menyebabkan banyak ditemukan nota-nota laundry yang mencantumkan klausula eksonerasi yang digunakan oleh penyedia jasa laundry di dalam masyarakat.

Pada dasarnya pihak pelaku usaha selalu mengedepankan prinsip ekonomi atau keuntungan dalam kegiatan usahanya tetapi kurangnya kualitas dan kuantitas dari kinerja pelaku usaha tersebut. Biasanya pelaku usaha tidak mempedulikan keluhan dari konsumen. Pelaku usaha lebih memfokuskan pada keuntungan dengan pengeluaran modal yang minim baik itu modal awal pembuatan jasa laundry ataupun untuk ganti kerugian yang sejalan dengan prinsip ekonomi. Pelaku usaha laundry tersebut menghindari penuntutan ganti kerugian dan menghindari tanggung jawab.

\subsubsection{Bentuk Pelaksanaan Pertanggungjawaban Pelaku Usaha Jasa Laundry Terhadap Konsumen Yang Mencantumkan Ketentuan Klausula Eksonerasi Pada Nota Laundry Di Desa Seminyak Kecamatan Kuta}

Dengan adanya kegiatan bisnis berupa pelayanan/jasa yang salah satunya laundry sudah pasti memiliki resiko yang cukup besar baik bagi pelaku usaha maupun konsumen terlebih resiko kerugian akibat penggunaan klausula eksonerasi lebih dilimpahkan kepada konsumen. Akibat kerugian tersebut, pelaku 
usaha harus memberikan ganti kerugian kepada pihak konsumen yang dirugikan akibat menggunakan jasa laundry dari salah satu pelaku usaha tersebut, dan pelaku usaha memiliki tanggung jawab kepada pihak konsumen.

Bahwasanya tanggung jawab merupakan keadaan dimana suatu pihak tersebut wajib menanggung segala resiko yang telah diperbuatnya dan jika nantinya terjadi sesuatu boleh dipersalahkan, diperkarakan, dll. Hal ini dikarenakan prioritas utama pelaku usaha membuka jasa laundry adalah sebagai kepuasan dan tercapainya kemudahan bagi konsumen guna memperoleh pemasukan. Konsumen yang dirugikan berhak untuk di dengar keluhannya dan berhak untuk menerima ganti kerugian dari pelaku usaha begitupun sebaliknya bagi pelaku usaha berkewajiban untuk mendengar dan memberikan ganti kerugian kepada konsumen dengan setara kerugian yang dialami konsumen. 6

Adanya ganti kerugian tersebut bertujuan untuk mengembalikan keadaan yang dimana sebelumnya rusak atau hancur dalam artian ini akibat yang tidak seimbang dengan pemakaian barang dan atau jasa yang tidak sesuai dengan harapan kebutuhan. ${ }^{7}$ Didalam peraturan perundang-undangan yang secara khusus mengatur mengenai tanggungjawab pelaku usaha ialah UUPK yang dalam hal ini diatur secara khusus mengenai tanggung jawab pelaku usaha yaitu termuat dalam Pasal 19 ayat (1) yang menentukan bahwa, pelaku usaha bertanggung jawab memberikan ganti rugi atas kerusakan,

6 Celina Tri Swi Kristiyanti, 2008, Hukum Perlindungan Konsumen, Cet.1, Sinar Grafika, Jakarta, h.169.

7 Ahmad Miru Sutarman Yodo, 2005, Hukum Perlindungan Konsumen, Rajawali Pers, Jakarta, h. 126. 
pencemaran, dan atau kerugian konsumen akibat mengkonsumsi barang dan atau jasa yang dihasilkan atau diperdagangkan

Sedangkan di dalam Pasal 19 ayat (2) Ganti rugi sebagaimana dimaksud pada ayat (1) dapat berupa pengembalian uang atau penggantian barang dan/atau jasa yang sejenis atau setara nilainya. Lalu di dalam ayat (3) Pemberian ganti rugi dilaksanakan dalam tenggang waktu 7 (tujuh) hari setelah tanggal transaksi. Dalam ayat (4) Pemberian ganti rugi sebagaimana dimaksud pada ayat (1) dan ayat (2) tidak menghapuskan kemungkinan adanya tuntutan pidana berdasarkan pembuktian lebih lanjut adanya unsur kesalahan. Sedangkan dalam ayat (5) Ketentuan sebagaimana dimaksud pada ayat (1) dan ayat (2) tidak berlaku apabila pelaku usaha dapat membuktikan bahwa kesalahan tersebut merupakan kesalahan kosnumen.

Bentuk tanggungjawab dari pelaku usaha yang mencantumkan klausula eksonerasi adalah tanggungjawab mutlak, karena prinsip tanggungjawab mutlak dalam hukum perlindungan konsumen secara umum digunakan untuk menjerat pelaku usaha, khususnya produsen yang merugikan konsumen. Asas tanggungjawab itu dikenal dengan nama product liability. Biasanya prinsip tanggungjawab mutlak ini diterapkan karena konsumen tidak dalam posisi menguntungkan. Menurut asas ini produsen wajib bertanggungjawab atas kerugian yang diderita konsumen atas penggunaan produk yang dipasarkannya. ${ }^{8}$

Pada umumnya perjanjian yang dibuat oleh pelaku usaha tersebut berisi klausula eksonerasi, adanya hal tersebut bertujuan untuk melimpahkan sebagian atau segala tanggungjawab yang mana mestinya tanggungjawab tersebut dilakukan oleh pelaku

${ }^{8}$ Shidarta, 2000, Hukum Perlindungan Konsumen Indonesia, PT Grasindo, Jakarta, h. 79. 
usaha dan merupakan beban dari pelaku usaha laundry namun kenyataannya berbeda sepenuhnya dilimpahkan kepada pihak konsumen. Sedangkan dalam pelaksanaanya seperti pada Quick Laundry dalam memberikan berupa ganti kerugian yaitu sebagai berikut:

a. Barang yang rusak atau hilang diganti dengan 5 kali ongkos cucian;

b. Cucian yang rusak karena bahan atau kain bukan tanggung jawab pelaku usaha;

c. Adanya barang-barang yang tertinggal didalam saku bukanlah tanggungjawab dari pelaku usaha.

Adanya ganti kerugian seperti diatas telah terjadinya pengalihan tanggung jawab sepenuhnya yang dimana pelaku usaha tidak bertanggung jawab apabila terjadi kerusakan, pelunturan warna pada pakaian dan rusaknya kain yang di laundry, namun pada kenyataannya kerusakan, pelunturan, dan mengkerutnya kain disebabkan oleh proses pencucian pada laundry tersebut.

Bentuk ganti kerugian Quick Laundry tidak sebanding atau tidak sesuai dengan peraturan UUPK pada Pasal 19 ayat (2) karena ganti kerugian hanya 5 kali ongkos pencucian dan jika pakaian yang hilang merupakan seharga Rp. 400.000 sedangkan ongkos cuci adalah Rp. 10.000 maka ganti kerugian tersebut tidak setara dan tidak sesuai dengan peraturan UUPK tersebut. Lalu berdasarkan pada hasil wawancara yang dilakukan terhadap pemilik usaha jasa Jayanata Laundry menyatakan bahwa ganti kerugian hanya diberikan setengah harga dari pakaian yang hilang atau rusak karena menurut pihak laundry bahwa barang yang sudah rusak ataupun hilang merupakan dalam kondisi yang sudah bekas. 
Bahwasanya ganti rugi bertujuan untuk mengembalikan keadaan seperti semula yang rusak dalam artian keadaan yang tidak seimbang akibat adanya penggunaan jasa atau pemakaian barang yang tidak sesuai harapan. ${ }^{9}$ Dengan demikian hal tersebut bertentangan dengan Pasal 4 huruf h UUPK yang menyatakan bahwa konsumen berhak mendapatkan ganti rugi, dan/atau penggantian, apabila barang dan/atau jasa tersebut tidak sesuai dengan perjanjian atau tidak sebagimana dengan mestinya.

Berdasarkan aturan tersebut, bentuk ganti kerugian dari kedua pelaku usaha laundry tersebut tidak sesuai dengan UUPK, karena terkait dengan barang yang rusak atau hilang diganti dengan setengah harga. Sedangkan untuk barang yang hilang atau rusak diganti dengan 5 kali ongkos pencucian dan adanya pakaian yang mengkerut, warna pakaian luntur bukanlah tanggungjawab dari pelaku usaha laundry. Hal tersebut tidak mencerminkan ganti kerugian dengan nilai yang setara sesuai dengan Pasal 19 ayat (2) sehingga sangat jelas terlihat bahwa bentuk ganti kerugian pelaku usaha laundry tersebut bertentangan dengan UUPK.

\section{PENUTUP}

\subsection{Kesimpulan}

Berdasarkan pembahasan tersebut dapat ditarik kesimpulan yaitu sebagai berikut:

1. Pelaku usaha laundry mencantumkan klausula eksonerasi karena pelaku usaha mempunyai hak dari adanya perjanjian yang dibuat secara sepihak dan harus disepekati

9 Ahmad Miru Sutarman Yodo, 2005, Hukum Perlindungan Konsumen, Rajawali Pers, Jakarta, h. 126 
oleh pihak konsumen. Akan tetapi pada Pasal 18 UUPK pelaku usaha dilarang mencantumkan klausula baku dan pelaku usaha tidak mengetahui bahwa itu dilarang oleh peraturan perundang-undangan dan pada prinsipnya pelaku usaha hanya mengedepankan prinsip keuntungan semata tanpa melihat kualitas serta kuantitas dari suatu jasa yang dihasilkannya.

2. Bentuk pertanggungjawaban dari pelaku usaha jasa dibidang laundry di Desa Seminyak Kecamatan Kuta yaitu bertanggungjawab atas kelalaian yang dilakukan oleh pihak pelaku usaha yang menyebabkan kerugian terhadap konsumen, akan tetapi pada pelaksanaanya pelaku usaha tidak mengikuti aturan UUPK adalah ganti rugi dengan nominal yang setara sebagai pertanggungjawaban sebagai pihak pelaku usaha terhadap konsumen yang mengalami kerugian.

\subsection{Saran}

Adapun saran yang dapat diberikan yaitu sebagai berikut:

1. Sebaiknya pelaku usaha mengedepankan kualitas serta kuantitas dari jasa yang diperdagangkan, agar nantinya tidak ada pengalihan tanggungjawab yang mana dibebankan seluruhnya kepada konsumen serta sebaiknya ada sosialisasi yang dilakukan oleh pemerintah terhadap pelaku usaha mengenai peraturan peundang-undangan.

2. Pelaku usaha hendaknya bertanggungjawab akibat terjadinya kelalaian yang merugikan konsumen dengan memberikan ganti kerugian yang setara dengan nominal dari barang yang rusak ataupun hilang tersebut dan 
tanggungjawab dari pelaku usaha laundry dan sesuai dengan ganti kerugian menurut UUPK yang berlaku. 


\section{DAFTAR PUSTAKA}

\section{Buku}

Ahmad Miru Sutarman Yodo, 2005, Hukum Perlindungan Konsumen, Rajawali Pers, Jakarta.

Fakultas Hukum Universitas Udayana, 2013, Pedoman Pendidikan Fakultas Hukum Universitas Udayana, Denpasar.

Shidarta, 2000, Hukum Perlindungan Konsumen Indonesia, PT Grasindo, Jakarta.

Soekanto, Soerjono, 2012, Pengantar Penelitian Hukum, UI-PRESS, Jakarta.

Kristiyanti, Celina Tri Swi, 2008, Hukum Perlindungan Konsumen, cet. 1, Sinar Grafika, Jakarta.

Yodo, Ahmad Miru Sutarman, 2005, Hukum Perlindungan Konsumen, Rajawali Pers, Jakarta.

Nasution, Az, 1995, Karya Ilmiah Tentang Perlindungan Konsumen dan Peradilan di Indonesia, Badan Pembinaan Hukum Nasional, Departemen Kehakiman RI.

\section{Jurnal Ilmiah}

Adi Lestari, Anak Agung, 2016, "Perjanjian Baku Dalam Jual Beli Kredit Sepeda Motor Ditinjau Dari Undang-Undang Nomor 8 Tahun 1999", Jurnal Magister Hukum udayana, Vol. 5, No. 2 ,

URL:https://ojs.unud.ac.id/index.php/jmhu/article/view/2 2445/15663. Diakses tanggal 22 April 2019.

Gde Agung Brahmanta, A.A, 2016, "Perlindungan Hukum Bagi Konsumen Dalam Perjanjian Baku Jual Beli Perumahan Dengan Pihak Pengembang Di Bali”, Acta Comitas Jurnal Hukum Kenoktariatan, Vol. 1, No. 02, URL : https://ojs.unud.ac.id/index.php/ActaComitas/article/view /24953/16186. Diakses tanggal 22 April 2019.

\section{Peraturan Perundang-Undangan}


Undang-Undang Nomor 8 Tahun 1999 tentang Perlindungan Konsumen (Lembaran Negara Republik Indonesia Tahun 1999 Nomor 42, Tambahan Lembaran Negara Republik Indonesia Nomor 3821 ). 